\title{
Venezuela 2019: A Tale of Two Presidents
}

Venezuela 2019: un relato de dos presidentes

\author{
ADRIANA BOERSNER \\ University of South Carolina Aiken, USA
}

\begin{abstract}
After opposition leader Juan Guaidó challenged Nicolás Maduro's leadership in January 2019, what has happened in Venezuela at the political, economic, and social levels? What has been the international response to the Venezuelan crisis? This paper aims to provide an overview of domestic processes that took place in Venezuela in 2019. It begins by highlighting the political challenge to the autocratic regime of Nicolás Maduro when the president of the National Assembly assumed the role of interim president of Venezuela. Then, it examines the main socioeconomic problems in Venezuela, and how the international community reacted to these challenges. The final section discusses the current situation of the regime and the opposition after a year of attempts at dialogue and negotiation.
\end{abstract}

Keywords: Autocracy, Juan Guaidó, Nicolás Maduro, Venezuela.

\section{RESUMEN}

Después de que el líder de la oposición Juan Guaidó desafió el liderazgo de Nicolás Maduro en enero de 2019, ¿qué ha sucedido en Venezuela a nivel político, económico y social? ¿cuál ha sido la respuesta internacional a la crisis venezolana? Este artículo tiene como objetivo proporcionar una visión general de los procesos internos que tuvieron lugar en Venezuela en 2019. Comienza destacando el desafío político y constitucional al régimen autocrático de Nicolás Maduro. Luego, examina los principales problemas socioeconómicos de Venezuela, y cómo la comunidad internacional reaccionó a estos desafios. La sección final discute la situación actual del régimen y el de la oposición tras un año de intentos de diálogos y negociación.

Palabras claves: Autocracia, Juan Guaidó, Nicolás Maduro, Venezuela. 


\section{INTRODUCTION}

Analysts and scholars (Coppedge 2002; Ellner 2003; Corrales and Penfold 2011; Levitsky and Roberts 2011; Mainwaring 2012) have debated for quite some time whether Venezuela could be considered as a democratic country. Recent literature, however, documents the erosion of democracy in Venezuela after the 2010s (Levitsky and Loxton 2013; López Maya 2016; Levitsky and Ziblatt 2018) in which Venezuela deepened its authoritarian features and embarked in an escalating political, economic, and social crisis. As in previous annual reviews in this journal (Sánchez Urribarrí 2016; Buxton 2018; Pantoulas and McCoy 2019), experts have recognized how this transition to authoritarianism in Venezuela progressively occurred on several fronts including the creation of parallel institutions to those already elected by the majority of voters; by celebrating elections that were not free or fair; by using repression against the population and political dissidents; by eliminating check and balances on the executive, among others.

In May 2018, a presidential election took place in Venezuela that was widely viewed as unfair and illegitimate by domestic and international actors. The results of this election functioned as the basis for what would happen in 2019 in Venezuela: a presidential crisis. The newly elected president of the National Assembly, Juan Guaidó, took up the role of interim President of Venezuela in January 2019, challenging the regime of Nicolás Maduro. After that, clashes erupted and rallies in support of Guaidó increased; Maduro lost his legitimacy in front of an important number of countries and other actors in the international community. By the end of the year, however, Guaidó and the political opposition struggled to gain control over the regime while Maduro's regime kept consolidating his power.

Besides the presidential confrontation between Maduro and Guaidó, other circumstances of significant importance co-existed in Venezuela including high levels of hyperinflation; violence and food shortages; scarcity of medicine and gasoline; and increased levels of migration of Venezuelans to Latin America and The Caribbean. The international community played an active role in the Venezuelan crisis when more than 50 countries and the Organization of American States recognized Guaidó as President of Venezuela while Maduro reinforced his alliances with China, Cuba, Iran, Russia, and Turkey.

This paper looks at these issues in turn. Although more space will be needed to go into detail to explain all events, this paper provides an overview of the noteworthy issues related to Venezuela in 2019. The second section offers a summary of the Venezuelan presidential crisis. The third section discusses the major socioeconomic developments concerning the economy and oil production, lack of basic services, protests, and the activity of Colombian armed groups in Venezuela. The fourth section analyzes the Venezuelan migration and refugee crisis. The fifth section offers an overview of the international community and its response toward the crisis in Venezuela. Finally, in the concluding section, there 
is an overview of the current state of the regime of Maduro and the Venezuelan opposition, as well as a brief discussion of the challenges to negotiate a solution to the Venezuelan crisis.

\section{A PRESIDENTIAL CRISIS IN REVIEW: A TALE OF TWO PRESIDENTS}

Since January 2019, two leaders have claimed to be the President of Venezuela. This presidential crisis came after the election of May 20, 2018, in which Nicolás Maduro was re-elected to a second six-year term by six million voters (Consejo Nacional Electoral 2018). This election, with a turnout of $46.02 \%$ was widely viewed as illegitimate by opposition groups and a large part of the international community (e.g., Council of the European Union 2018; Ministerio de Relaciones Exteriores de Peru 2018). To begin with, the regime engaged in at least two strategies of election manipulation (Schedler 2002). ${ }^{1}$ One, restricting political and civil liberties as the election took place within an environment of systematic state repression against members of the opposition and civil society. Second, the exclusion of opposition forces. The election was proved to be minimally competitive. Maduro's principal rivals or nationally recognized opposition leaders were either in exile, in jail, or banned from participation in elections.

Other irregularities included changing the day of the election. The election was to be held in December, not May 2018. Also, the election was a call made by the National Constituent Assembly (ANC), created by Maduro in July 2017 to rewrite the Constitution and is comprised of Maduro's supporters, as well as by the board of the National Electoral Council, appointed by a government-controlled Supreme Court. The ANC is not supported by the National Assembly nor recognize by the international community. Due to these irregularities, the validity of the election was put into question.

On January $5^{\text {th }}, 2019$, the National Assembly -a public branch dominated by opposition parties- elected the new president of the National Assembly, Juan Guaidó. On January $10^{\text {th }}$, the pro-regime chief of the Supreme Court of Justice, Maikel Moreno, sworn Maduro in as president of Venezuela -even when the elected president should have been sworn in before the National Assembly, according to article 231 of the Constitution. ${ }^{2}$ Guaidó and the opposition ignored Maduro's oath as President of Venezuela and, on January $22^{\text {nd }}$, the National Assembly assumed the powers of the executive. The day after, in front of a public crowd in Caracas and members of the National Assembly, Guaidó stated that

For a recent overview of electoral irregularities and democratic backsliding in Venezuela between 1999 and 2019 see Corrales (2020a).

Article 231 of the constitution also states that if "for any reason the President of the Republic is unable to take possession before the National Assembly, he will do so before the Supreme Court of Justice." The National Assembly refused to proclaim Maduro as President of Venezuela for another six years. 
the May election had made the office of the President vacant and that Maduro was not the legitimate President of Venezuela. Therefore, according to the 1999 Constitution, the second in line, the President of the National Assembly, should be declared the interim President of Venezuela while new elections should be organized. On January 23 ${ }^{\text {rd }}$, Guaidó was sworn in as Venezuela interim President of Venezuela.

Since then, the country has been caught in a conflict between the tail of two presidents: Juan Guaidó -who controls one of the public branches of government, elected by universal suffrage, and has major international recognition-, and Nicolás Maduro-who has the power and effective control of the regime and the territory but lacks legitimacy after the 2018 May election. But who exactly is Juan Guaidó and how did he become interim president of Venezuela?

In January 2019, not many people inside and outside Venezuela knew about Juan Guaidó. Since the opposition won a majority of the seats in the National Assembly on 6 December 2015, he has been a lawmaker of the National Assembly for the Voluntad Popular political party. Back then, political parties signed a rotation agreement guaranteeing representation of all major parties in the board of directors that the Assembly would have in its five-year term. In 2019, the presidency fell to the Voluntad Popular party and the turn of Guaido to be elected. Juan Guaidó became a visible leader due to the judicial problems faced by other leaders of the Popular Will party, like the deputy Freddy Guevara. Guevara was accused of instigating violence by the Supreme Court and had to seek refuge at the Chilean embassy in Caracas in 2017. At that time, Guevara was the vice-president of the National Assembly.

Now, answers regarding the legality of Guaidó's actions and how he became interim president of Venezuela have consist of many political and constitutional arguments (Herrera Orellana 2019; Macía Briedis 2019; Seijas-Bolinaga 2019) that expand beyond the explanation below. Ultimately, the National Assembly took the 1999 Venezuelan Constitution and two articles to allow Guaidó to be named interim President. On the one hand, Article 233 of the Constitution refers to absolute absence or abandonment (falta absoluta o abandono) and states that,

The President of the Republic shall become permanently unavailable to serve by reason of any of the following events: death; resignation; removal from office by decision of the Supreme Tribunal of Justice; permanent physical or mental disability certified by a medical board designated by the Supreme Tribunal of Justice with the approval of the National Assembly; abandonment of his position, duly declared by the National Assembly; and recall by popular vote. When an elected President becomes permanently unavailable to serve prior to his inauguration, a new election by universal suffrage and direct ballot shall be held within 30 consecutive days. [...] (Constitution of the Bolivarian Republic of Venezuela 1999)

According to this article, Juan Guaidó, as President of the National Assembly, had to take on the responsibilities of the executive given the absence or aban- 
donment of the elected president. Seijas-Bolinaga (2019) argues that since the National Assembly rejected the May election due to major irregularities, in the absence of an elected president, the constitutional remedy and duty of the National Assembly was to restore the constitutional mandate contained in article 233. However, the absolute absence and abandonment detail in this article does not say much about what happens when there is a presidential election that has been denounced as fraudulent.

On the other hand, article 333 states that

This Constitution shall not cease to be in effect if it ceases to be observed due to acts of force or because or repeal in any manner other than as provided for herein. In such eventuality, every citizen, whether or not vested with official authority, has a duty to assist in bringing it back into actual effect. (Constitution of the Bolivarian Republic of Venezuela 1999)

This article allows every citizen with the duty to support the restoration of the Constitution's validity if the Constitution has been violated. The opposition not only declared Maduro's absence in office but also accused him of infringing the rule of law by violating human rights. Accordingly, article 333 was invoked by Guaidó to propose three steps to end the presidential crisis: 1) the end of the usurpation; 2) the formation of a transitional government, and 3) free and fair elections. Guaidó revealed a sector-by-sector reconstruction plan call Country Plan (Plan País) that details actions to rebuild the country once Maduro is removed from power. However, how exactly the three steps were going to be achieved was not clear.

After assuming the interim presidency and receiving formal recognition of legitimacy from more than 50 countries, Juan Guaidó embarked on various domestic and international efforts to end Maduro's power. One of them took place on February $23^{\text {rd }}$ when Guaidó and his supporters, along with the help of some countries including Canada, Chile, Colombia, the United States, and some European countries, urged Maduro to allow shipments of humanitarian aid through to alleviate the scarcity of food and medicines. However, in the previous days, Maduro rejected the aid and sent tankers and shipping containers to block the border with Colombia and Brazil. Since then, Venezuela's borders with Brazil and Colombia, as well as the maritime borders with Curacao, Aruba, and Bonaire, have been intermittently closed. After the aid did not enter Venezuela, an unknown number of low-ranking Venezuelan military personnel defected or went hiding.

Another effort took place on April 30 ${ }^{\text {th }}$. Juan Guaidó, the leader of his political party, Leopoldo López, ${ }^{3}$ along with a small group of soldiers and a group of supporters gathered near the airbase, La Carlota, in Caracas in the so-called

The last time Leopoldo López was seen free was in February 2014. The regime of Nicolás Maduro arrested him and condemned him for almost fourteen years in prison. Since 2017, López was under house arrest. 
"Operation Freedom." The goal was to build bridges with members of the Armed Forces and rebel against Maduro. However, assault vehicles sent by Maduro's regime drove through the crowds, scattering the protesters. Within a few hours, the small group of soldiers who had joined Guaido sought refuge in the Brazilian Embassy. As Mijares and Cardozo Uzcátegui (2020) suggest, Guaidó's main mistake was trying to force the Armed Forces to split with Maduro as a necessary condition to create breaks within the ruling coalition.

Also at the domestic level, Guaidó made repeated calls for small-scale and national demonstrations including protests to demand the end of Maduro's regime; reject the national blackouts in March, April, and July; gather support during the uprising on April $30^{\text {th }}$ against Maduro; and reject the death of a corvette captain of the Armed Force, who was tortured while in prison. However, by the end of the year, these efforts and the three steps that were set in January by Guaidó were not accomplished. According to a poll conducted by Meganálisis (2019) between November and December 2019, 85.3\% of the surveyed did not support the National Assembly and $68.5 \%$ did not trust Juan Guaidó. Nevertheless, according to a poll conducted by the local pollster Datanalisis (Tal Cual 2019), in October 2019, Guaidó remained as the leader with more support in Venezuela (42\%).

At the international level, Guaidó appointed ad honorem ambassadors in countries that recognized Guaidó as interim President of Venezuela and battled for the control over the assets of the U.S refiner Citgo -a U.S subsidiary of Venezuela's national oil company. Guaidó also challenged the regime when he traveled to Latin America in February-March, even when the Supreme Court banned Guaidó from leaving the country and froze his bank accounts. On March 4, 2019, Juan Guaidó returned to Venezuelan with the support of a group of ambassadors from European countries and the U.S. chargé d'affaires in Venezuela.

In practice, however, nothing changed. Nicolás Maduro remained in power and as a chief commander of the Armed Forces. The National Assembly continued to be unable to have the power to legislate in 2019. Maduro dismissed Guaidó's claim to the presidency, calling it part of an American-led plot. In January 2019, after the United States and other countries in Latin America recognized Guaidó as interim president of Venezuela, Maduro expelled the last U.S diplomats that were at the U.S Embassy in Caracas (Ministerio del Poder Popular para las Relaciones Exteriores 2019). Though the United States government announced that Maduro did not have the authority to break diplomatic relations, in March, the United States suspended its diplomatic operations in Venezuela. Consequently, the Swiss embassy has been the protector of the U.S. embassy in Caracas (Agencia EFE 2019). In February, Maduro also announced the interruption of diplomatic relations with Colombia and expelled a delegation of the European People's Party (EPP) minutes after landing in Venezuela. The delegation had been invited to Venezuela by Juan Guaidó. 
At the domestic level, Maduro's levels of support were around 25\% by May 2019 (Alarcón 2019), which contrasted with the 8.7\% level of support he kept by the end of the year (Meganálisis 2019). Maduro's support was still noticeable in protests to demand the United States to keep its "hands-off" of Venezuela and to reject the economic sanctions imposed by the United States on Venezuela. Beyond the social base that still supports Maduro, there are armed groups like Colectivos ${ }^{4}$ that have been important in countering marches called by the opposition. Both, in February and April 2019, members of the Colectivos played an important role in confronting Guaido and his supporters on the streets (Sheridan and Zuñiaga 2019).

Maduro also continued to chase and detain dissidents. Some members of the National Assembly promptly fled the country. In Caracas, security officers surrounded Guaidó's Vice-President, Edgar Zambrano, and took him to intelligence headquarters. Another thirteen legislators had their parliamentary immunity revoked. By mid-2019, Maduro had in prison a considerable number of active and retired officers (Corrales 2020b). However, hard-liners military continued to recognize Maduro as the legitimate president and commander in chief (Otis 2019). Military officers, police officers, and state surveillance were vital in 2019 for the regime to retain power and had control over the population. This was noticeable during multiple protests and between April 30th and the first week of May, when 7 protesters were killed by security forces, and 346 individuals were wounded by bullets, pellets, and tear gas inhalation (Observatorio Venezolano de Conflictividad Social 2019). According to Foro Penal (2020), at least 50 people were killed as a consequence of excessive force against protesters and 2,219 people were arbitrarily arrested for political reasons.

\section{MAJOR SOCIO-ECONOMIC DEVELOPMENTS IN VENEZUELA IN 2019}

\section{The economy and oil production}

Secondary sources (Organization of the Petroleum Exporting Countries 2019) have reported that the Venezuelan oil production declined from 3,3 million barrels per day in 1998 close to 697,000 barrels per day in November 2019. This has been a dramatic situation for a rentier economy that bases $95 \%$ of its exports on oil. The drop in oil production and revenues have been the result of several domestic and international conditions including the fall in oil prices since 2014; lack of foreign and national investment and maintenance of the national oil company Petróleos de Venezuela S.A, (PDVSA); and international sanctions 
imposed on PDVSA. Also, there has been a lack of cash flow since a big part of Venezuelan oil production is consumed in the domestic market or used to repay loans given by China, Russia, and other countries (Monaldi 2018).

Due to the decline of oil production and the freefall of the economy, illegal gold mining activities amplified in 2019. Proceeds from the illegal extraction of the gold strengthened not only corrupt state officials, such as the minister of industries and national production, Tareck El Aissami, or the head of the corps of special inspectors of the presidency, Nicólas Maduro Guerra, but also armed groups including the National Liberation Army (ELN), the Revolutionary Armed Forces of Colombia (FARC), and local mafias, so-called sindicatos (International Crisis Group 2019; Bargent and Rainsford 2020; Rendon et al 2020).

In the absence of reliable economic and financial data, there have been different estimations regarding the level of inflation in the country. The International Monetary Fund (IMF), for example, estimated that by the end of 2019, Venezuela will see inflation levels of 10,000,000\% (Reuters 2018) whereas the Central Bank of Venezuela estimated an inflation level of 9,585.50\%. Whether the IMF or the Central Bank was right, the reality is that Venezuelans have had a persistent loss of purchasing power because of hyperinflation and the mismanagement of the economy. Contrary to Maduro's various increases in the minimum wage (a total of 26 in six years), the problem has not been solved.

In November 2019, Nicolás Maduro embraced the possibility of accepting transactions in U.S dollars after the national currency, the Bolivar, depreciated more than 90\%. ${ }^{5}$ In an interview (France 24 2019), Maduro said that there was nothing wrong about the use of the dollar in Venezuela and, in fact, the dollarization could serve for the recovery of the economy. Sutherland (2019) suggests that three events were important in understanding Maduro's change of mind and his decision to accept the informal use of the dollar.

The first event was the collapse of the economy. In 2018, after launching without major success, a cryptocurrency called El Petro, and a second monetary reconversion, levels of inflation and scarcity of basic goods rose steeply. The second event was the national electrical blackout that occurred between March and April of 2019. Venezuela's electrical grid crashed, and consecutive electric shutdowns went out all over the country. The lack of electricity and money encouraged citizens to buy and sell in other currencies such as the dollar, euro, and Colombian pesos. The third event was the impact of economic sanctions against Venezuela. These sanctions have limited the Central Bank of Venezuela to have access to dollars and limited the oil company PDVSA to sell oil. 


\section{Lack of basic services, food, and medicines}

Before 2019, Venezuelans were already facing severe shortages of food, medicines, potable water, and fuel. But these and other problems accentuated in 2019. A survey conducted by the Venezuelan Public Services Observatory (Observatorio Venezolano de Servicios Públicos) (2019) revealed that during the 2019 March national electric blackout, citizens faced various difficulties such as finding food, appliances' damage, as well as lack of potable water and domestic gas. In some states, like Zulia, the blackout lasted for weeks. The effects on the population have been devastating since then. The internet failed, the water stopped running, and hospitals scrambled to keep incubators and dialysis machines going. By November 2019, the distribution of water through the pipes was only $23 \%$, even though $91 \%$ of the citizens had access to water pipes. Also, $50 \%$ of citizens informed that they experienced electric shutdowns every day. Regarding access to the internet, around $60 \%$ of people had access, and $53 \%$ experienced service problems every day.

Due to the numerous challenges to have basic services such as water, electricity, and domestic gas, $23 \%$ of citizens reported their willingness to migrate to another country. Most respondents indicated that they would migrate to countries in Latin America (41\%), Europe (11\%), or the United States $(7 \%)$, while $16 \%$ of respondents were willing to move to other cities within Venezuela (e.g., Caracas and Valencia).

\section{Unrests and attacks by state security forces}

Due to continuous waves of violation of human rights before and during 2019, members of a technical mission of the Office of the United Nations High Commissioner for Human Rights visited Venezuela in March 2019. The technical mission preceded the visit to Venezuela of the High Commissioner, Michelle Bachelet. On July 5, 2019, Bachelet's office presented a comprehensive report regarding the human rights situation in the country between January 2018 and May 2019. The report shows a deterioration of the economic and social rights as the Venezuelan economy contracted, the oil production decreased, and inflation levels rose steeply (UN Human Rights Office of the High Commissioner 2019).

Due to the political and socio-economic developments in Venezuela, protests continued to take place in 2019. According to The Armed Conflict Location \& Event Data Location (2020), three specific developments motivated protests and riots in Venezuela. ${ }^{6}$ The first was the recurring electric blackouts across Venezuela caused by failures in the country's hydroelectric generation system during the months of March, April, and July. The second was the leadership of Juan Guaidó. Once Guaidó challenged the leadership of Nicolás Maduro,

The Venezuelan Observatory of Social Conflict shows a higher number of protests and demonstrations. However, the OVCS disaggregated data, is not freely available. 
several demonstrations started to take place across the country in support of Guaidó. The third was demands made by health workers, teachers, and public workers to respect their collective contracts, request the dollarization of their wages, as well as demand the distribution of food and basic services between September and November of 2019.

Figure 1. Number of protests and riots in Venezuela in 2019

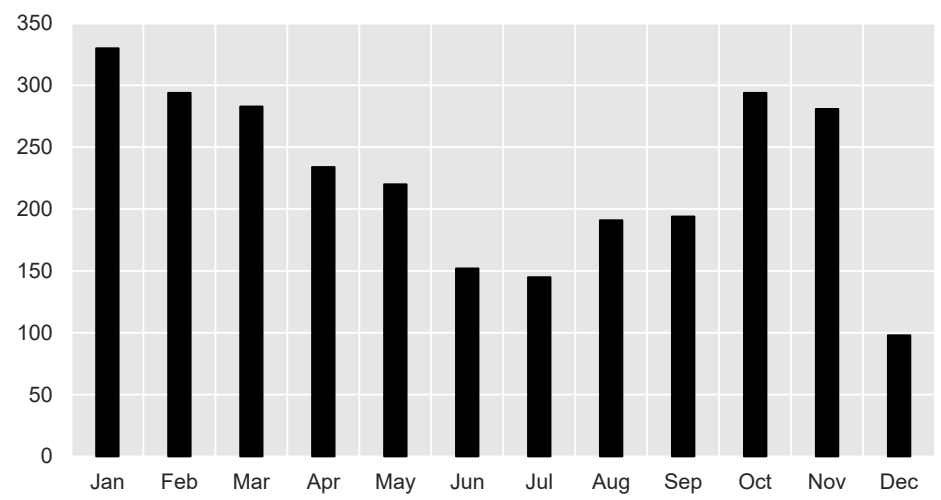

Source: The Armed Conflict Location \& Event Data Project.

Various local and international organizations also revealed another problem: extrajudicial killings conducted by state security forces toward political dissidents and civilians. Only in 2018, 5,287 people were killed by state forces, allegedly, due to "resistance to authority" and more than 1,569 people were killed between January and May 2019 (UN Human Rights Office of the High Commissioner 2019). Most of these attacks keep taking place in low-income communities and go unpunished. Although major police reforms took place since 2006 (Gan 2020), the widespread of extrajudicial killings incremented abruptly after the creation in 2017 of a special unit called Special Action Forces (FAES), and the preeminence of the militarization of citizen security forces. Frequently, the UN Human Rights Office of the High Commissioner, Human Rights Watch, and local organizations have called the regime of Nicolás Maduro not to use FAES and other police forces' actions to maintain social control. However, the regime has not responded to these demands.

\section{Increasing activities of Colombian armed groups and drug cartels in Venezuela}

Armed groups, including the Colombian Revolutionary Armed Forces (FARC), the National Liberation Army (ELN), People's Liberation Army (EPL), and 
United Self-Defense Forces of Colombia (AUC), have been present in Venezuela for years. Particularly, the ELN and FARC have been in border states even before Hugo Chávez took power in 1999 (Boraz 2007). However, after 1999 these groups have progressively taken control of certain territories to establish drug trafficking corridors and illegal mining activities. In the southern state of Bolívar, for example, ELN members have clashed with local mafias or sindicatos, as well as local communities for the control of mines and drug trafficking corridors between Venezuela and Brazil and Venezuela and Colombia. In 2019, local and international organizations reveal that there was a presence of members of the ELN in states beyond Bolívar state such as Amazonas, Apure, Táchira, and Zulia, with new bases in Barinas Falcón, Guárico, and Lara states (FundaRedes 2019; InSight Crime 2020). ELN's activities have exposed to terror local and vulnerable communities such as indigenous groups and miners (International Crisis Group 2019; Rendon et al 2020), which has pushed local communities to migrate (to avoid death) or be constantly threatened (and face death) by these armed groups.

Additionally, at least six dissident FARC groups have bases in Venezuelan territory (FundaRedes 2019) and Mexican drug cartels are operating in Zulia state, near the border with Colombia, as a point for international drug trafficking (InSight Crime 2020). Since 2018, the non-governmental organization, FundaRedes, has documented this presence and how Colombian guerrillas have control over illegal crossings between Colombia and Venezuela, the economy, health, food distribution, as well as school activities. It has been documented by FundaRedes (2018), for instance, how guerrillas have recruited children and teenagers in Venezuela to join their groups.

\section{MIGRATION AND REFUGEE CRISIS}

The socio-economic developments saw in Venezuela before 2019 enhanced the massive migration that started in 2015. Several countries in Latin America and The Caribbean experienced, however, an increase of Venezuelan migrants in 2019, which led some countries to require Venezuelan migrants to meet certain requirements to enter their countries.

Table 1. Number of Venezuelan Migrants by Country in Latin America and The Caribbean

\begin{tabular}{lcccc}
\hline \multirow{2}{*}{ Countries } & \multicolumn{2}{c}{ Is a visa required for Venezuelans? } & \multicolumn{2}{c}{ Total number of Venezuelan migrants } \\
& 2015 & Dec 2019 & $2015^{* *}$ & July 2019** \\
\hline Argentina & No & No & 12,856 & 145,000 \\
Bolivia & No & No & $?$ & 5,000 \\
Brazil & No & No & 3,425 & 168,357 \\
Chile & No & Yes & 8,001 & 288,233 \\
\hline
\end{tabular}




\begin{tabular}{|c|c|c|c|c|}
\hline \multirow{2}{*}{ Countries } & \multicolumn{2}{|c|}{ Is a visa required for Venezuelans? } & \multicolumn{2}{|c|}{ Total number of Venezuelan migrants } \\
\hline & 2015 & Dec 2019 & $2015^{* *}$ & July $2019^{* *}$ \\
\hline Colombia & No & No & 48,714 & $1,408,055$ \\
\hline Costa Rica & No & No & 6,437 & 25,700 \\
\hline $\begin{array}{l}\text { D o m in - } \\
\text { ican Re- } \\
\text { public }\end{array}$ & No & Yes & 5,417 & 28,500 \\
\hline Ecuador & No & Yes & 8,901 & 330,414 \\
\hline Guyana & Yes & $\mathrm{No}^{*}$ & $?$ & 17,000 \\
\hline Mexico & No & No & 15,959 & 46,072 \\
\hline Panama & No & Yes & 9,883 & 94,400 \\
\hline Paraguay & No & No & 88 & 449 \\
\hline Peru & No & Yes & 2,351 & 853,429 \\
\hline $\begin{array}{l}\text { Trinidad } \\
\text { and Toba- } \\
\text { go }\end{array}$ & No & Yes & 1,732 & 40,000 \\
\hline Uruguay & No & No & 1,855 & 8,589 \\
\hline
\end{tabular}

*The requirement of the visa is not enforced.

** Estimation based on population statistics, migration records, and estimations from the International Organization for Migration.

Sources: International Organization for Migration (2019); Selee and Bolter (2020).

According to the United Nations High Commissioner for Refugees (UNHCR) between 2014 and November 2019, more than 3 million Venezuelans fled the country. Also, according to the UNHCR, death threats and diseases were the major drives for most Venezuelan to leave Venezuela. Some of these migrants have qualified for refugee status in their host country. Still, many Venezuelans remain in an irregular situation because they are asked to meet the financial and legal requirements that are difficult to obtain (Saavedra 2020). As such, their legal status has made them vulnerable to exploitation and abuse.

While the crisis continues, Venezuelans are still in the middle, looking for ways to survive the crisis. Women and children have been the most vulnerable groups in the Venezuelan migration. In South America, Venezuelan women and children are at greater risk, for example, of sexual exploitation and human trafficking (Chavez 2020). Children are at risk of being recruited into gangs and cartels, while Venezuelan women have been killed due to common violence and xenophobia.

\section{THE INTERNATIONAL COMMUNITY}

At the beginning of 2019, Venezuela was at the epicenter of most world news since the country had two presidents. Immediately, three aspects emerged at the international level as a consequence of the Venezuelan turmoil. The first was the international support given to each Venezuelan leader. The second was 
the different multilateral mechanisms and dialogues that attempted to serve as a negotiated solution for the Venezuelan crisis. The third was the extension of economic sanctions imposed on Venezuela.

\section{Nicolas Maduro's international support}

The international support that Nicolás Maduro managed to keep in 2019 relied mostly on strong historical alliances linked to Chavismo such as Cuba, China, Iran, and Russia, and the interest of these countries in retaining Maduro in power including present and future gains (e.g., Cuba), protect their investments and assets (e.g., China and Russia), or mere convenience (e.g., Turkey-new ally).

Cuba. ${ }^{7}$ Synthesizing the Cuba-Venezuela relationship is not an easy task and would take more space than the one allowed in this paper. Certainly, there has been much speculation about the presence of Cuban doctors, Cuban military officers, and Cuban intelligence advisers in Venezuela (Fonseca et al 2020). This uncertainty is due to the nature of the Cuban and Venezuelan political regime, and the secrecy of the Cuban regime's actions on Venezuelan soil. Before 2013, the years in which oil prices were high, Venezuela was able to economically support Cuba. Today, Venezuela is no longer receiving the same revenues to afford such economic costs. Likewise, several aspects of the bilateral partnership have been abandoned. However, far from ending the long bilateral partnership, Maduro still relies on Cuban intelligence personnel and Cuban-style repressive actions to hold into power.

China and Russia. Xi Jinping and Vladimir Putin became two of the main international supporters of Maduro during the crisis that started in January 2019. On the one hand, before Maduro took power in 2013, Russia already had significant economic, financial, and geopolitical interests in Venezuela. However, as Boersner and Haluani (2013) state, the Russian-Venezuelan relationship derived from the initial personal interest of the executive branch once Hugo Chávez and Vladimir Putin came to power. Since 2006, Russia has loaned to Venezuela nearly $\$ 10$ billion for buying fighter jets and $\$ 1.1$ billion for oilfield (Herbst and Marczak 2019). These loans, along with the spread of protests and political crisis, pushed Russian military specialists to go to Venezuela in April 2019 to protect local Russian interests. In 2019, Venezuela received from Russia technical military personnel, financial transactions, and facilitation of oil shipments (Rouvinski 2019) but not new credits. With China, Russia blocked a United Nations resolution that may have facilitated a United Nations peace enforcement force to help Juan Guaidó to consolidate his control over the Venezuelan regime.

Initially, the government of Evo Morales in Bolivia supported Nicolás Maduro. That changed after the presidential election and the head of the Senate, Jeanine Añez Chávez, declared herself Bolivia's interim president. Añez supported Juan Guaidó as interim President of Venezuela. In Central America, Nicaragua has been the only country supporting Nicolás Maduro. 
On the other hand, between 2007 and 2016, China granted around \$62.1 million in bank loans to Venezuela (Gallagher and Myers 2017). In 2019, China provided parts and equipment to Venezuelan refineries. Although the Chinese foreign minister showed initial support to Nicolás Maduro in January 2019 and rejected a possible intrusion of the U.S into the internal affairs of Venezuela, later the minister announced that the Chinese government maintained close contacts with all parties involved in the Venezuelan crisis. This announcement was an indication of China's long-term interests in Venezuela and a motive to continue doing business and protect its investments in the event of a regime change in Venezuela.

Iran. While the diplomatic relationship between Iran and Venezuela goes back to 1947, since the election of Mahmoud Ahmadinejad in August 2005 as president of Iran, there has been a rapprochement between Iran and Latin America, especially with Venezuela and Bolivia (Brun 2007). The common denominators have been an anti-American ideology and the desire to provide an alternative front to what they consider American imperialism. Oil is at the center of Iran and Venezuela's economic cooperation, but the relationship is also based on three other pillars: the political, military, and cultural. Despite sanctions imposed on Iran and Venezuela, the bilateral relationship continues. In 2020, Venezuela has received help from Iran to repair its oil refineries in addition to receiving fuel supplies in the midst of U.S economic sanctions imposed on both countries.

Turkey. The relationship with the Turkish government is fairly recent and has been strong since 2016. The Turkish-Venezuelan partnership is an alliance of short-term mutual convenience that has allowed the sale of Venezuelan gold to Turkey in exchange for food and medicine. Between January and September 2018, 24 tons of unrefined gold was transported to Turkey. According to Meléndez and Boon (2019), the gold was exported by the Central Bank of Venezuela and has been investigated since then by agencies in Europe to determine if this is blood gold. Oner (2020) argues that Turkey's relationship with Maduro's government responds to anti-Americanism sentiments, as well as to economic gains.

Maduro also has the support of the Colombian guerrilla of the National Liberation Army (ELN) and FARC dissidents. These armed groups have been increasing their operations in Venezuelan territory without being disturbed by the government (International Institute for Strategic Studies 2011; Martínez 2017). Connections between the ELN and the regime have expanded on various fronts. One of them is ideological since Colombian guerrillas have declared themselves Bolivarian as the Maduro's regime. Another one is economic. The ELN and FARC dissidents are present in key states where they can charge extortion to local communities and companies to allow illegal activities to flow, including illegal mines (Corrales 2020b; Rendon et al 2020), and hide drug trafficking business and corridors. ${ }^{8}$

Ramsey and Smilde (2020) show that the relative role of Venezuela as a transit country of drug trafficking is minor considering that $84 \%$ of the cocaine movement goes to the United States via Colombia, Ecuador, and Peru while only $7 \%$ goes through Venezuela. 
Finally, at the beginning of 2019, Mexico and Uruguay worked in favor of a dialogue between the two parties without demanding new elections in Venezuela or recognizing Juan Guaidó. Later, Uruguay moved closer to the European position and requested a dialogue together with new elections. Following a change in Presidential administrations from Enrique Peña Nieto (Institutional Revolutionary Party) to Andrés López Obrador (National Regeneration Movement), Mexico favored and moved closer to Maduro's side. Since his inauguration as president-elect of Mexico, López Obrador has approached the crisis in Venezuela based on the principles of no intervention in the internal affairs of other countries and no rejection of other governments.

\section{Juan Guaidó's international support}

The United States of America and Latin America. From that moment on, various governments in Latin America extended their recognition to Guaidó including Brazil, Canada, Argentina, Peru, Colombia, Chile, Costa Rica, Guatemala, Honduras, Panama, and Paraguay, as well as the Organization of American States. El Salvador joined these countries that have aligned themselves against Maduro after the new president, Nayib Bukele, broke the policy maintained by his predecessor, Salvador Sánchez Cerén. The electoral shift saw in Latin America in the last five years away from leftist policies including Brazil, Bolivia, Chile, Ecuador, Paraguay, Peru, and Uruguay, largely explains the support given to Guaidó.

For Latin American countries, there have been important reasons for engaging in meaningful pressures toward Maduro's regime. First, the consequences of various waves of migration and internal turmoil that have brought complex domestic dynamics in many countries, especially in Colombia. The crisis has pushed countries like Colombia to absorb the arrival of Venezuelan refugees often in poor health and malnourished. Inherently, it is no secret that Venezuelan migrants and refugees have seen an increase of xenophobic discourses and movements against them (Molina 2019). For example, in Ecuador, Venezuelans have been linked to crime rates. In Peru, marches were called and banners were placed rejecting the presence of Venezuelans. In Panama, marched were also called to highpoint that Venezuelan migrants were harming the country's economy and displacing local workers. Second, if countries do not act simultaneously, Venezuela might end up insulating itself even more. This means that without some sort of accountability, Maduro will keep up arresting opposition leaders, repressing civilians, as well as deepening the humanitarian crisis in Venezuela.

Europe. The response from the U.S and Latin American countries was immediate, which contrasted with the strategy implemented by members of the European Union (EU). This process of recognition of Guaidó varied in time and 
across European countries. Initially, the Spanish government was more cautious about adopting a position toward the Venezuelan crisis. After numerous meetings and negotiations to find a common position, the government of Pedro Sánchez gave Maduro eight days to start a process that would end in presidential elections. The condition was never met by Maduro. After the term expired, 20 of the 28 European countries, including the United Kingdom, recognized Guaidó as president-in-charge. The refusal, among others, of Italy, Greece, and Austria (which finally recognized Guaidó), prevented a unanimous position within the European community bloc. Greece's initial position might be explained by the political and ideological proximity of its government to the Venezuelan. After the Greek legislative election was held in July, Greece followed the European Union's line and recognized Guaidó. The relationship between Italy and Hungary with the EU certainly impacted their approach toward the crisis in Venezuela and the possibility of joining a common front against Maduro. Consider how Italy and Hungary have faced backlash and sanctions from other members of the EU given their stance against immigration (the case of Hungary) and refusing to follow the EU fiscal rules (the case of Italy).

Beyond Latin America, The U.S, and Europe, Guaidó received other important endorsements, such as that of Israel, Morocco, and Australia, all in good relations with the United States. Ukraine's attitude was significant, given its difficult relationship with Russia.

\section{Multilateral Mechanisms}

Various mechanisms of negotiations and dialogues ${ }^{9}$ were undertaken since 2017 to contribute to a peaceful resolution of the crisis. Some of the mechanisms created with international support were the Lima Group (created in August 2017), the International Contact Group, and the Montevideo Mechanism. Some of the reasons to create these mechanisms and seek for a solution to the crisis in Venezuela are the growing polarization in the international community to either support Maduro or Guaidó; the Venezuelan socioeconomic crisis that comprises the collapse of the economy, food and medicine scarcity, ramp up corruption, among others; and the effects that waves of migration from Venezuela are having on other countries, particularly in South America.

The first mechanism, The Lima Group, favors Juan Guaidó and is comprised of 13 Latin American countries and Canada. After meeting in early February in Ottawa, the Lima Group signed a statement reiterating their support for the interim president and rejecting the use of external force to resolve the crisis in Venezuela. The Group aimed at three things: create any diplomatic initiative that could put Guaidó's proposed roadmap underway; promote a peaceful transition that achieves Maduro's departure; and call for a transparent and 
fair electoral process afterward. The group rejected dialogues with the regime, considering that Maduro has used these to delay negotiations and perpetuate himself in power. Three members do not recognize Guaidó as President of Venezuela: Mexico, Guyana, and Saint Lucia.

The second mechanism, The International Contact Group on Venezuela, promoted by the European Union, held the first meeting in Montevideo early in February 2019. This mechanism maintains that new elections with a credible process are necessary for Venezuela instead of dialogues with no preconditions. Since the beginning, the contact group has recognized that Maduro and his elite have not committed to previous talks and have not acted in good faith. The contact group backed other initiatives such as the dialogue process initiated by Norway and coordinating efforts with the Lima Group.

The third mechanism, The Montevideo Mechanism comprises Uruguay, Mexi$\mathrm{co}$, and 14 countries of the Caribbean Community. Mexico and Uruguay, in response to the call of United Nations Secretary-General, Antonio Guterres, agreed that dialogues and negotiations are the way to address the complex situation in Venezuela. For this reason, the mechanism was created to seek peace in Venezuela in four stages: dialogue, negotiation, commitments, and implementation (El País 2019). While Nicolás Maduro supported the Montevideo Mechanism from the beginning, Guaidó reiterated that he would participate in the dialogue only in order to work out an exit of Maduro's regime.

As Meucci (2019) asserts, an underlying problem in these negotiations and dialogues has been the perception that both sides are equivalent when they are not. While Maduro's regime has arms and means to repress, the opposition does not have control of the territory and the Armed Forces. These asymmetries, coupled with the lack of incentives for members of the regime to leave power (Marsteintredet 2020) and the lack of unity and clear strategy within the opposition, has resulted in empty dialogues like the one facilitated by Norway.

\section{Sanctions on Venezuela}

The academic literature warns about the potential consequences of imposing economic and financial sanctions on other countries (Peksen and Drury 2009; Drury and Peksen 2012; Early and Peksen 2019; Bull and Rosales 2020). Most of this literature has documented the negative effects of sanctions on the targeted country such as accessibility of food, potable water, and medicines, as well as on women's status, informal economies, and political liberties. Although the use of economic and financial sanctions has been praised for avoiding the use of force abroad, the effects on the economy and the society could be devastating, depending on the type and frequency of these sanctions.

In 2019, Maduro and members of his regime saw a significant ramping up of sanctions against them, as well as third parties linked to the Venezuelan govern- 
ment. While the package of sanctions increased, compared to previous years, so the intensity of the discourse by the U.S President and spokespersons of the U.S government which maintained that "all options were on the table" (Caputo and Orr 2019), even a military option. ${ }^{10}$ While other actors in the international community did not engage in this confrontational discourse toward Maduro and members of his regime, the level of polarization seen within Venezuela was exported, perhaps for the very first time, to the international level. More than 50 countries recognized the leadership of Juan Guaidó and a handful of countries also sanctioned the Venezuelan regime, besides the U.S, including Canada, Colombia, Mexico, Switzerland, and members of the European Union.

This was an important move considering that most sanctions on Venezuela have been imposed by the U.S (56.86\%), as figure 2 shows. In September 2019 , sixteen governments across the Americas, which previously recognized Guaidó as interim president, agreed to activate a regional defense pact known as the Rio Treaty ${ }^{11}$ (formally known as the Inter-American Treaty of Reciprocal Assistance or TIAR) and announced their intention to impose sanctions to members of the Maduro's regime, in addition to pursuing, capturing and extraditing Venezuelan officials involved in illegal activities. ${ }^{12}$

Figure 2. Percentage of sanctions on Venezuela per sender (2006- April 2020)

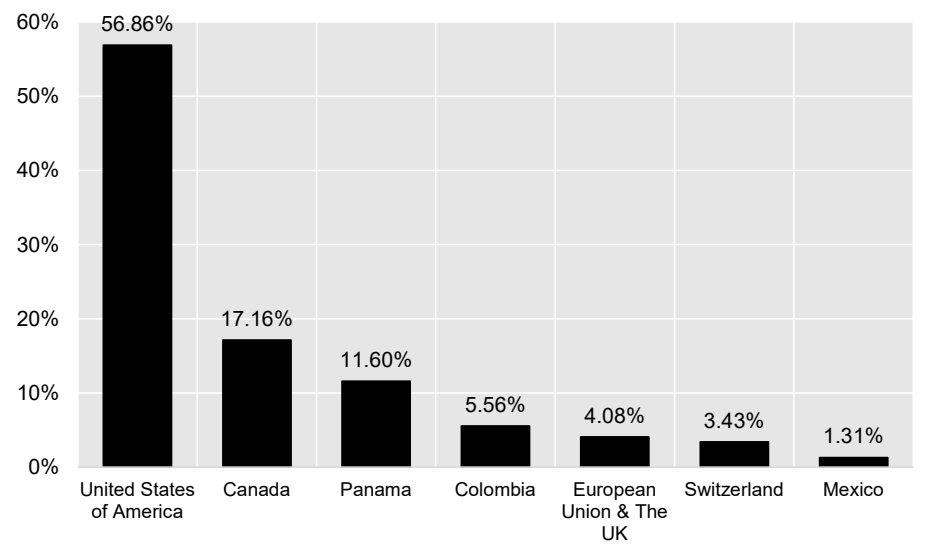

Author's dataset

Note: The U.S sanctions include the aggregate of individuals in the government that have been sanctioned by the U.S government, individuals in connection with the government of Venezuela, and companies according to various policy instruments used to implement these sanctions (Executive orders 13692 and 13850; the Foreign Narcotics Kingpin Sanctions Regulations, and the Global Terrorism Sanctions Regulations). which rejects the use of force in Venezuela and endorses a diplomatic and negotiated solution to the crisis.

11 In 2014, Nicolás Maduro withdrawn from the Treaty. In August 2019, the National Assembly deposited an instrument of accession which was accepted.

12 Uruguay voted against and Trinidad and Tobago abstained. 
Figure 3 shows that $63.24 \%$ of these sanctions have been imposed on individuals and $16.01 \%$ on companies connected to the Venezuelan regime. ${ }^{13} 19.93 \%$ have been sanctions imposed on ships and aircraft connected to the Venezuelan regime and $0.82 \%$ (Government) have been sanctions on state companies, bonds, or control of exports of military technology and equipment (e.g., from Europe). Despite much discussion of the militarization of the Maduro regime and the role of the military, the fact that $41.75 \%$ of the targeted sanctions are mostly on civilians and not the military $(16.98 \%)$, speaks to the power they have within the government.

Figure 3. Percentage of sanctions on Venezuela by target 2006-2020

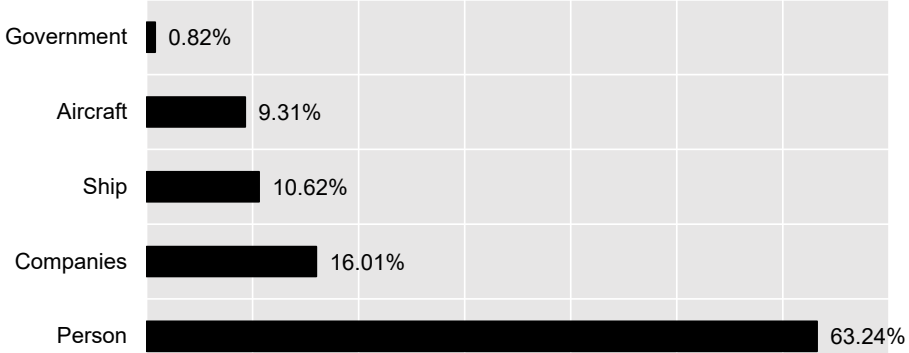

Author's dataset

The discussion over the consequences that these sanctions have had on the Venezuelan economy and social domain is an ongoing and controversial one (Hausmann and Muci 2019; Weisbrot and Sachs 2019). In terms of the political effects, the results have shown the little effect that sanctions have had in changing Maduro's behavior. On the one hand, the individual sanctions on members of the government have not encouraged them to abandon Maduro. Maybe, the only notorious case was the now-former Director of the Bolivarian National Intelligence Service, General Manuel Cristopher Figuera, who was sanctioned by the U.S and then removed from the list after he defected on April 2019. On the other hand, the economic and financial sanctions, although they have limited Maduro's move at the international level, have not deterred him to work with partners such as India, Iran, Russia, and Turkey to sell gold and oil. Also, not all U.S sanctions have been immediately enforced. The US Treasury Department, for example, allowed companies like Chevron and other oil companies to continue their operations in Venezuela for some more months after sanctions were imposed.

13 In the long run, these sanctions have also had an impact on private companies operating in Venezuela including the software company Adobe and AT\&T (Long 2019; Reuters 2020). 


\section{CONCLUSIONS: WAS IT THE BEGINNING OF THE END OF MADURO'S REGIME USURPATION?}

Despite the scope of the economic and social problems in Venezuela and the leverage the opposition had, some discourses at the domestic and international levels may have underestimated the power that Maduro still has. The complex domestic situation in Venezuela and the international support given to the Venezuela opposition, as crucial as they were for generating a possible change in Maduro's behavior, were not able to create a solid breach within the ruling elite or create the pathway for Maduro's exit. Instead, Maduro has remained in power; harrasing the inner circle of Juan Guaidó, citizens, and military who have defected; rearranging his support within his own elite and managing to divert some of the international sanctions imposed on Venezuela.

After a tumultuous 2019, what is the current situation of Nicolás Maduro and the opposition? what are some of the ongoing implications of the Venezuelan crisis for the international community? By February 2020, there were no unusual activities reported in Venezuela, a sign, perhaps, of political and social fatigue. While Guaidó kept his international exposure afloat when he made his almost three weeks long tour between January and February 2020 in Latin America, Europe, and North America, Maduro restated his control over the state, the economy, and the territory. This has been even more notorious in the midst of the coronavirus outbreak around the world.

On the one hand, the Venezuelan regime keeps retaining power based on five factors: state repression toward dissidents; the financing of illegal activities that have increased due to a collapsing economy and oil production; the social control applied through attacks by state security forces and the few social assistance programs that remain; and a reduce group of international alliances and domestic support. As long as these factors are not weakened, the regime of Maduro can be maintained over time.

The fifth factor is related to Guaidó's weaknesses to understand Maduro's permanence in power. Juan Guaidó set three goals: to remove Maduro from power, establish a transitional government, and call for new elections. These objectives were not achieved. As the leader of the Venezuelan opposition, Guaidó's failure to create a break within the ruling elite can be understood due to at least four factors. The first was an indecisive speech. Guaido's speech initially appealed to a pacific resolution of the crisis. However, Guaidó's close relationship with the United States led him to announce that all options were indeed on the table (and under the table), including the military.

The second was the lack of real control over the territory, economic resources, and the Armed Forces. It was a mistake to assume on April $30^{\text {th }}$ that military officers would abandon the regime with few guarantees while there was a confrontational domestic and international discourse targeting them. The possibility of the regime's support, especially the one coming from the hard-liners 
military, collapsing in the face of double international and national pressure is feasible but would require credible guarantees.

The third was corruption scandals and disagreements within the opposition. The corruption scandal of a group of opposition legislators associated with the illegal business to distribute food bags in Venezuela and the corruption scandal over the misappropriation of the money that was donated to Venezuela in early 2019 was not good news for Guaidó and his leadership. Parallel talks held by a small group of opposition parties with the regime and public disagreements have also shown that the opposition is far from being a common front to bring down Maduro's power.

Finally, the progressive disconnection between groups of the civil society and Juan Guaidó that started after some organizations that carry out humanitarian work questioned the political use of international humanitarian aid. This disconnection was reflected in much of the protests seen during the second half of 2019, mostly organized by workers from different economic sectors and not necessarily in response to Guaidó's calls. Even when Guaidó remains popular, his levels of approval decreased over time given that he has not been able to deliver what he promised.

Many analysts and members of the international community have said that the role of other countries is not decisive to solve the crisis in Venezuela. They claim that what happens internally will be even more crucial. However, having failed the dialogues between the regime and the opposition, two realistic questions to ask are, what is next if none of the parties involved in dialogues are willing to put their interests aside? What exactly needs to happen internally to solve the crisis?

Considering the historical context and the purpose of dialogues to solve the political crisis, both sides should approach the negotiations realistically and coherently, as well as take responsibility for their actions (Cannon and Brown 2017; Lowenthal and Smilde 2019). Yet, since mid-2019, members of Maduro's regime have not been willing to dialogue with the head and major parties of the opposition-controlled National Assembly-but with a minority group within the opposition (Guns 2019). The lack of a clear strategy and unitary front within the opposition has also impacted its willingness to negotiate with members of Maduro's regime. This situation was even disclosed by the U.S Secretary of State, Mike Pompeo, who mentioned that keeping the opposition together has been difficult (The Washington Post 2019). This does not come as a surprise when some leaders of the opposition have been demeaning negotiations and dialogues for years.

The sole interest of removing Maduro and members of his cabinet is not going to be feasible if the characteristics and nature of the regime, as well as the needs of the society, are not well understood by the opposition. This is a necessary pre-condition for a political transition toward democracy (Linz and Stepan 
1996; Geddes 1999). Considerations for weakening the hegemonic party and how to include important actors in future dialogues such as local organizations, the church, groups from the civil society, and militaries are also critical since they could play a relevant role in a future political transition. Finally, international allies of the regime and the Venezuelan opposition need to be able to act in a manner sufficiently impactful- without recurring on extreme pressures or unilateral tactics- to alter the current position of both sides toward a possible solution of the crisis.

\section{REFERENCES}

Agencia EFE. 2019, 16 May. "Suiza "Está Preparada" Para Proteger La Embajada En Venezuela." Retrieved on July 10, 2020 from https:/ /www.efe.com/efe/usa/politica/suiza-esta-preparada-para-proteger-la-embajada-en-venezuela/50000105-3978207

Alarcón, Benigno. 2019, 21 June. "El Efecto Guaidó." Politika UCAB. Retrieved on July 19, 2020 from https:/ / politikaucab.net/2019/06/25/el-efecto-guaido/

Bargent, James. and Cat Rainsford. 2020. "Gamechangers 2019: Illegal Mining, Latin America's Go-To Criminal Economy." InSight Crime. Retrieved on April 27, 2020 from https://www.insightcrime.org/news/analysis/gamechangers-2019-illegal-mining-criminal-economy/

Boersner, Adriana. and Makram Haluani. 2013. "Convergencias Y Divergencias en La Asociación Estratégica Ruso-Venezolana Y Sus Implicaciones Hemisféricas." Cuadernos del CENDES 30(82): 67-107.

Boraz, Steven. 2007. "Case Study: The Colombia-Venezuela Border." In Ungoverned Territories: Understanding and Reducing Terrorism Risks, edited by Angel Rabasa, Steven Boraz, Peter Chalk, Kim Cragin, Theofore W. Karasik, Jennifer D.P. Moroney, Kevin A O’Brien, and John E. Peters. Santa Monica: Rand Corporation, 243-276.

Brun, Elodie. 2007. "Iran's Place in Venezuelan Foreign Policy." Arnson, C., Esfandiari, H. y Stubits, A. Iran in Latin America: Threat or 'Axis of Annoyance. Woodrow Wilson International Center for Scholars. Latin American Program and Middle East Program.

Bull, Benedicte. and Antulio Rosales. 2020. "Into the Shadows: Sanctions, Rentierism, and Economic Informalization in Venezuela." European Review of Latin American and Caribbean Studies 109: 107-133.

Buxton, Julia. 2018. "Venezuela: A Las Puertas Del Abismo." Revista de Ciencia Política 38(2): 409-428.

Cannon, Barry. and John Brown. 2017. "Venezuela 2016: El Año De Vivir Peligrosamente." Revista de Ciencia Política 37(2): 613-634.

Caputo, Marc. and Gabby Orr. 2019, 18 February. "Trump: All Options Are on the Table for Venezuela." Politico. Retrieved on May 15, 2020 from https://www.politico.com/ story/2019/02/18/trump-speech-venezuela-1173606

Chavez, Angela. 2020, 5 March. "Venezuelan Women: The Unseen Victims of The Humanitarian Crisis." The Atlantic Council. Retrieved on July 10, 2020 from https://www. atlanticcouncil.org/blogs/new-atlanticist/venezuelan-women-the-unseen-victims-of-the-humanitarian-crisis/

Consejo Nacional Electoral. 2018, 21 May 21. Retrieved on April 28, 2020 from http:/ /www. cne.gov.ve/web/sala_prensa/noticia_detallada.php?id=3716

Constitution of the Bolivarian Republic of Venezuela. 1999. Retrieved on June 30, 2020 from http://hrlibrary.umn.edu/research/venezuela-constitution.html

Coppedge, Michael. 2002. "Venezuela: Popular Sovereignty Versus Liberal Democracy." Kellogg Institute for International Studies, Working Paper \#294. Retrieved on June 30, 2020 from https://kellogg.nd.edu/documents/1587 
Cooper, Andrew F. 2020. "Recalibrando Los Modelos Clásicos De Mediación: Exlíderes Políticos E Iniciativas De Redes De Personalidades Híbridas en La Crisis De Venezuela." Revista de Ciencia Política 40(1): 27-47.

Corrales, Javier. and Michael Penfold-Becerra. 2011. Dragon in the Tropics: Hugo Chávez and the Political Economy of Revolution in Venezuela. Washington D.C: Brookings Institution Press.

Corrales, Javier. 2020a. "Democratic Backsliding Through Electoral Irregularities: The Case of Venezuela." European Review of Latin American and Caribbean Studies 109: 41-65.

Corrales, Javier. 2020b. “Why Maduro Hasn't Fallen." Journal of Democracy 31 (3): 39-53.

Council of European Union. 2018, 22 May. "Declaration by The High Representative on Behalf of The EU on The Presidential and Regional Elections in Venezuela." Retrieved on July 16, 2020 from https://www.consilium.europa.eu/en/ press / press-releases / 2018/05/22/declaration-by-the-high-representative-on-behalf-of-the-eu-on-the-presidential-and-regional-elections-in-venezuela/

Drury, A. Cooper. and Dursun Peksen. 2012. "Women and Economic Statecraft: The Negative Impact International Economic Sanctions Visit on Women." European Journal of International Relations 20 (2): 463-490.

Early, Bryan. and Dursun Peksen. 2019. "Searching in the Shadows: The Impact of Economic Sanctions on Informal Economies." Political Research Quarterly 72(4): 821-834.

Ecoanalítica. 2019, November 20. "Gráfico De La Semana: Euros soberanos." Retrieved on April 28, 2020 from https:/ / ecoanalitica.com/graficodelasemana-euros-soberanos/

Ellner, Steve. 2003. "The Contrasting Variants of the Populism of Hugo Chávez and Alberto Fujimori." Journal of Latin American Studies 35(1): 139-162.

El País. 2019, 6 February. "Uruguay y México Presentaron El "Mecanismo De Montevideo" Para Crisis En Venezuela." Retrieved on 1 July, 2020 from https: / /www.elpais.com.uy/ informacion/politica/canciller-mexicano-uruguay-reunio-vazquez-nin-novoa.html

Fonseca, Brian., John Polga-Hecimovich. and Richard Feinberg. 2020. “Venezuela and Cuba: The Ties That Bind." The Woodrow Wilson Center. Latin American Program.

Foro Penal. 2020, 23 January. "Political Repression in Venezuela. Report." Retrieved on July 20, 2020 from https://foropenal.com/en/political-repression-in-venezuela-report-2019/

France 24. 2019, 19 November. “Nicolás Maduro: No Veo Nada Malo En Eso Que Llaman Dolarización." Retrieved in July 1, 2020 from https:/ / www.france24.com/es / 20191119-nicol\%C3\%A1s-maduro-no-veo-nada-malo-en-eso-que-llaman-dolarizaci\%C3\%B3n

FundaRedes. 2019, 13 September. "FundaRedes Consignó Nuevo Informe Sobre Presencia De Guerrilla Colombiana En Venezuela." Retrieved on 27 April, 2020 from https:/ / www.fundaredes.org/2019/09/13/fundaredes-consigno-nuevo-informe-sobre-presencia-de-guerrilla-colombiana-en-venezuela/

FundaRedes. 2018, 11 September. "Boletín 007: Jóvenes Venezolanos Son Reclutados Por Grupos Armados Irregulares En La Frontera." Retrieved on 27 April, 2020 from https:/ / www.fundaredes.org/2018/09/11/boletin-007-jovenes-venezolanos-son-reclutados-por-grupos-armados-irregulares-en-la-frontera/

Gallagher, Kevin. P. and Margaret Myers. 2017. China-Latin America finance database. Washington D.C: Inter-American Dialogue.

Gan, Natalia. 2020. "Rule of Law Crisis, Militarization of Citizen Security, and Effects on Human Rights in Venezuela." European Review of Latin American and Caribbean Studies 109: 67-86.

Geddes, Barbara. 1999. "What Do We Know About Democratization After Twenty Years?" Annual Review of Political Science 2 (1): 115-144.

Guns, Phil. 2019, 19 September. "Maduro Finds a "New Opposition" to Negotiate With." Crisis Group. Retrieved on July 7, 2020 from https:/ / www.crisisgroup.org/latin-america-caribbean/andes/venezuela/maduro-finds-new-opposition-negotiate

Hausmann, Ricardo and Frank Muci. 2019, 1 May. “Don't Blame Washington for Venezuela's Oil Woes: A Rebuttal." Americas Quarterly. Retrieved on July 7, 2020 from ht- 
tps://www.americasquarterly.org/article/dont-blame-washington-for-venezuelas-oil-woes-a-rebuttal/

Herbst, John E. and Jason Marczak. 2019, 12 September. "Russia's Intervention in Venezuela: ¿What's at Stake?" Atlantic Council. Retrieved on June 1, 2020 from https://www. atlanticcouncil.org/in-depth-research-reports/report/russias-intervention-in-venezuela-whats-at-stake/

Herrera Orellana, Luis A. 2019, 24 January. “Crisis Política en Venezuela: La Institucionalidad Que Debe Primar." Libertad y Desarrollo. Retrieved on March 2, 2020 from https:/ / lyd.org/centro-de-prensa/noticias/2019/01/crisis-politica-en-venezuela-la-institucionalidad-que-debe-primar/

International Crisis Group. 2019, 28 February. “Gold and Grief in Venezuela's Violent South. Latin America Report N ${ }^{\circ} 3$ ". Retrieved on April 15, 2020 from https:/ /www.crisisgroup.org/latin-america-caribbean/andes/venezuela/073-gold-and-grief-venezuelas-violent-south

International Organization for Migration. 2019. "Migration Trends in The Americas: Bolivarian Republic of Venezuela." Retrieved on April 15, 2020 from https:/ /www.iom.int/ external/migration-trends-americas-bolivarian-republic-venezuela

InSight Crime. 2020, 3 April. "Mexican Cartels-Venezuela's Uninvited Guests Here to Stay." Retrieved on April 15, 2020 from: https://www.insightcrime.org/news/analysis/ mexico-cartels-uninvited-guest-venezuela/

International Institute for Strategic Studies. 2011. The FARC Files: Venezuela, Ecuador, and The Secret Archives of Raúl Reyes. London: International Institute for Strategic Studies.

Levitsky, Steven. and Kenneth M. Roberts. (Eds.). 2011. The resurgence of the Latin American left. Washington DC: John Hopkins University Press.

Levitsky, Steven. and James Loxton. 2013. "Populism and competitive authoritarianism in the Andes." Democratization 20(1): 107-136.

Levitsky, Steven. and Daniel Ziblatt. 2018. How democracies die. New York: Crown Publishing. Linz, Juan José and Alfred Stepan. 1996. Problems of Democratic Transition and Consolidation: Southern Europe, South America, and Post-Communist Europe. Washington D.C: John Hopkins University Press.

Long, Gideon. 2019, 28 October. "U.S to Allow Adobe to Do Business in Venezuela." Financial Times. Retrieved on July 20, 2020 from https://www.ft.com/content/c119da7e-f99611e9-a354-36acbbb0d9b6

López Maya, Margarita. 2016. El Ocaso Del Chavismo: Venezuela 2005-2015. Venezuela: Editorial Alfa.

Lowenthal, A. and David Smilde. 2019. "Venezuela: Is There a Way Out of Its Tragic Impasse?" Woodrow Wilson Center for Scholars.

Macía Briedis, Rafael. 2019, 14 March. "The Venezuelan Presidential Crisis: A Response." International Journal of Constitutional Law Blog, Retrieved on July 1, 2020 from http:// www.iconnectblog.com/2019/03/the-venezuelan-presidential-crisis-a-response/

Mainwaring, Scott. 2012. "From Representative Democracy to Participatory Competitive Authoritarianism: Hugo Chávez and Venezuelan Politics." Perspectives on Politics 10(4): 955-967.

Marsteintredet, Leiv. 2020. "With the Cards Stacked Against You: Challenges to a Negotiated Transition to Democracy in Venezuela." European Review of Latin American and Caribbean Studies 109: 87-10.

Martínez, Luis. 2017. “Transnational Insurgents: Evidence from Colombia’s FARC at The Border with Chávez's Venezuela." Journal of Development Economics 126: 138-153.

Meganálisis. 2019, 2 December. "Estudio de opinión en Venezuela." Retrieved on July 3, 2020 from http:/ / www.encuestadorameganalisis.com/2-de-diciembre-20191.html

Meléndez, Lorena. and Lisseth Boon. 2019, 21 March. "How Venezuela's Stolen Gold Ended up in Turkey, Uganda, and Beyond." InSight Crime. Retrieved on July 3, 2020 from https://www.insightcrime.org/news/analysis/venezuelas-stolen-gold-ended-turkey-uganda-beyond/ 
Meucci Martínez, Miguel. Á. 2019. “La Necesidad De Romper Patrones En Las Negociaciones Por Venezuela." Diálogo Político. Retrieved on April 1, 2020 from https:/ /dialogopolitico.org/ debates/la-necesidad-de-romper-patrones-en-las-negociaciones-por-venezuela/

Meucci Martínez, Miguel. Á. and Francisco Pareja Alfaro. 2020. “Asimetría Del Conflicto Y Mecanismos Alternos De Diálogo Y Negociación En Venezuela (2002-2019)." América Latina Hoy: 1-21.

Mijares, Víctor. M. and Alejandro C. Uzcátegui. 2020. “Militares Bajo Control: Fallas Teóricas Detrás Del Estancamiento De Juan Guaidó." Foreign Affairs Latinoamérica 20(2): 64-74.

Ministerio de Relaciones Exteriores del Estado Peruano. 2018, 21 May. "Declaración del Grupo de Lima." Retrieved on July 15, 2020 from https:/ / www.gob.pe/institucion/rree/ noticias/4569-declaracion-del-grupo-de-lima

Ministerio del Poder Popular Para Las Relaciones Exteriores. 2019, 12 March. "Comunicado. Venezuela Expulse Diplomáticos Estadounidenses Remanentes En El País." Retrieved on July 1, 2020 from http://mppre.gob.ve/comunicado/venezuela-eeuu-oficina-intereses/

Molina, Víctor. 2019, 12 December. “Los Venezolanos No Solamente Sufrimos En Venezuela.” The Washington Post. Retrieved on July 1, 2020 from https:/ / www.washingtonpost.com/es/ post-opinion/2019/12/12/los-venezolanos-no-solamente-sufrimos-en-venezuela/

Monaldi, Francisco. 2018. “The Collapse of The Venezuelan Oil Industry and Its Global Consequences." The Atlantic Council: 1-11.

Observatorio Venezolano de Conflictividad Social. 2019, 15 May. "Situación De La Conflictividad en Venezuela en Abril De 2019." Retrieved on April 1, 2020 from http:// www.observatoriodeconflictos.org.ve/tendencias-de-la-conflictividad/1-963-protestas-se-contabilizaron-en-venezuela-durante-abril

Observatorio Venezolano de Servicios Públicos. 2019, 26 November. “¿Qué Pasa Con Los Servicios Públicos en Venezuela? Resultados De La Nueva Encuesta Sobre Percepción De Los Servicios Públicos Y Comparación Anual." Boletín N 5. Retrieved on April 1, 2020 from http:/ / www.observatoriovsp.org/wp-content/uploads/Boletin-N\%C2\%BA-5_26-noviembre-2019_8.pdf

Oner, Imdat. 2020. "Turkey and Venezuela: An Alliance of Convenience." Woodrow Wilson International Center for Scholars, Latin American Program, and the Middle East Program.

Organization of the Petroleum Exporting Countries. 2019, 11 December. OPEC monthly oil market report. Retrieved on April 2, 2020 from https:/ /www.opec.org/opec_web/static_files_project/images/content/publications/OPEC_MOMR_December_2019.pdf

Otis, John. 2019, 25January. "Why Venezuela's Military May BeStanding By Maduro, For Now." NPR. Retrieved on July 16, 2020 from https:/ / www.npr.org/2019/01/25/688576099/ tense-political-standoff-continues-in-crisis-wracked-venezuela

Pantoulas, Dimitris. and Jennifer McCoy. 2019. "Venezuela: an Unstable Equilibrium." Revista de Ciencia Politica 39(2): 391-408.

Pareja, Francisco. A 2020. "Archipiélagos Políticos Bajo La Tormenta en Venezuela: Coaliciones, Actores Y Autocratización." European Review of Latin American and Caribbean Studies 109.

Peksen, Dursun. and Andrew. Cooper. 2009. "Economic Sanctions and Political Repression: Assessing the Impact of Coercive Diplomacy on Political Freedoms." Human Rights Review 10(3): 393-411.

Ramsey, Geoff. and David Smilde. 2020. "Beyond the Narcostate Narrative: What U.S Drug Trade Monitoring Data Says About Venezuela." WOLA Advocacy for Human Rights in the Americas. Retrieved on April 1, 2020 from https://www.wola.org/analysis/beyond-the-narco-state-narrative-what-u-s-drug-trade-monitoring-data-says-about-venezuela/

Rendón, Moises, Linnea Sandin and Claudia Fernandez. 2020, April. "Illegal Mining in Venezuela: Death and Devastation in the Amazonas and Orinoco Regions." Center for Strategic and International Studies. Retrieved on July 2, 2020 from https:/ /www.jstor. org/stable/pdf/resrep24248.pdf 
Reuters. 2018, 9 October. "IMF Sees Venezuela Inflation at 10 Million Percent in 2019." Retrieved on July 18, 2020 from https://in.reuters.com/article/venezuela-economy/ imf-sees-venezuela-inflation-at-10-million-percent-in-2019-idINKCN1MJ1YX

Reuters. 2020, 19 May. "AT\&T Shuts Venezuela Subscription TV Unit, Citing U.S. Sanctions." Retrieved on July 20, 2020 from https://www.reuters.com/article/us-at-t-venezuela/att-shuts-venezuela-subscription-tv-unit-citing-u-s-sanctions-idUSKBN22V227

Rouvinski, Vladimir. 2019. "Russian-Venezuelan Relations at A Crossroads." Woodrow Wilson International Center for Scholars, Latin American Program, 1.

Saavedra, Horacio. 2020. “Migración Venezolana." Foreign Affairs Latinoamérica 20(2): 24-31.

Sánchez Urribarri, Raúl. 2016. "Venezuela (2015): Un Régimen Híbrido En Crisis." Revista de Ciencia Política 36(1): 365-381.

Schedler, Andreas. 2002. "Elections Without Democracy: The Menu of Manipulation." Journal of Democracy 13(2): 36-50.

Selee, Andrew. and Jessica Bolter. 2020. "An Uneven Welcome: Latin American and Caribbean Responses to Venezuelan and Nicaraguan Migration." Migration Policy Institute. Retrieved April 15, 2020 from https:/ / www.migrationpolicy.org/research/latam-caribbean-responses-venezuelan-nicaraguan-migration

Seijas-Bolinaga, Rolando. 2019, 21 February. "The Venezuelan Presidential Crisis." International Journal of Constitutional Law Blog. Retrieved on July 1, 2020 from http://www.iconnectblog.com/2019/02/the-venezuelan-presidential-crisis/

Sheridan, Mary B. and Mariana Zuñiaga. 2019, 14 March. “Maduro's Muscle: Politically Backed Motorcycle Gangs Known as 'Colectivos' Are the Enforcers for Venezuela's Authoritarian Leader." The Washington Post. Retrieved on July 20, 2020 from https:// www.washingtonpost.com/world/the_americas/maduros-muscle-politically-backed-motorcycle-gangs-known-as-colectivos-are-the-enforcers-for-venezuelas-authoritarian-leader/2019/03/13/2242068c-4452-11e9-94ab-d2dda3c0df52_story.html

Sutherland, Manuel. 2019. “¿Una Dolarización Antimperialista? O Cómo Desapareció El Dinero en Venezuela." Nueva Sociedad. Retrieved on April 27, 2020 from https://nuso. org/articulo/venezuela-Maduro-dolarizacion/

Tal Cual. 2019, 9 August. "82,2\% Del País Quiere Que Maduro Abandone El Poder Antes De Que Termine 2019." Retrieved on July 1, 2020 from https:/ / talcualdigital.com/el-rechazo-a-maduro-alcanzo-851-segun-el-ultimo-sondeo-de-datanalisis/

The Armed Conflict Location \& Event Data Project (ACLED). 2020. "Disorder in Latin America: 10 Crises In 2019." Retrieved on April 15, 2020 from https://acleddata. com/2020/03/12/disorder-in-latin-america-10-crises-in-2019/

The Washington Post. 2019, 6 June. "Exclusive: In Secret Recording, Pompeo Opens up About Venezuelan Opposition, Says Keeping It United 'Has Proven Devilishly Difficult." Retrieved on June 17, 2020 from https://www.washingtonpost.com/world/national-security/exclusive-pompeo-opens-up-about-venezuelas-opposition-says-keeping-it-united-has-proven-devilishly-difficult/2019/06/05/85385a33-8eae-4ba5-a9 ac-6b7b8c3d5762_story.html

UN Human Rights Office of the High Commissioner. 2019, 4 July. “UN Human Rights Report on Venezuela Urges Immediate Measures to Halt and Remedy Grave Rights Violations." Retrieved on May 5, 2020 from https://www.ohchr.org/en/NewsEvents/ Pages/DisplayNews.aspx?NewsID $=24788 \&$ LangID $=\mathrm{E}$

Weisbrot, Mark, and Jeffrey Sachs. 2019. "Punishing Civilians: U.S Sanctions on Venezuela." Challenge 62(5): 299-321.

Zerpa, Fabiola. 2019, 5 November. "Venezuela Is Now More Than 50\% Dollarized, Study Finds." Bloomberg. Retrieved on May 11, 2020 from https://www.bloomberg.com/ news/articles/2019-11-05/venezuela-is-now-more-than-50-dollarized-study-finds

Received: April 15, 2020

Accepted: July 20, 2020 
Adriana Boersner is an assistant professor at the Department of History, Political Science, and Philosophy at the University of South Carolina, Aiken. Her current research is on authoritarian politics, Venezuelan Foreign Policy, and leaders' personality. Email: Adriana.Boersner@usca.edu Twitter@AdriBoersner. 
